\title{
Heparin attenuates low-dose streptozotocin-induced immune diabetes in mice and inhibits the Beta-cell binding of T-splenocytes in vitro
}

\author{
P.Saï, S. Pogu and M. Ouary \\ Laboratoire d'Immunologie du Diabète, Faculté de Médecine, Nantes, France
}

\begin{abstract}
Summary. Five low doses $\left(40 \mathrm{mg} \cdot \mathrm{kg}^{-1} \cdot \mathrm{day}^{-1}\right)$ of streptozotocin were given to CD-1 mice to induce "immune" diabetes with insulitis. T-splenocytes (L3T4 ${ }^{+}$and Lyt $2^{+}$) from streptozotocin-treated mice were previously reported to display in vitro an increased binding for Beta cells, preceding the onset of hyperglycaemia and of insulitis. Since heparin inhibits lymphocyte traffic, displays anti-adhesive properties, and attenuates some cell-mediated immune diseases, we have investigated the effects of heparin and $\mathrm{N}$-desulphated heparin: 1 ) in vivo on low-dose streptozotocin-induced diabetes and insulitis, and 2) in vitro on the increased binding of T-splenocytes from streptozotocin-treated mice to rat insulinoma (RINm5F) cells. Daily subcutaneous low doses (5 $\mu \mathrm{g}$ or $10 \mu \mathrm{g}$ ) of heparin induced a delay in onset and a reduction of the severity of hyperglycaemia and insulitis $(p<0.01)$, and reduced the incidence of diabetes $(p<0.01)$. Similar effects swere obtained with $5 \mu \mathrm{g}$ daily doses of N-desulphated heparin devoid of anticoagulant activity. In contrast, lower
\end{abstract}

$(1 \mu \mathrm{g})$ or higher $(200 \mu \mathrm{g})$ doses of heparin were ineffective. Heparin $(10 \mu \mathrm{g})$ did not modify the "toxic" diabetes induced by a single high dose $(200 \mathrm{mg} / \mathrm{kg})$ of streptozotocin. On the other hand, heparin dose-dependently $(0.1 \mu \mathrm{g} / \mathrm{ml}$ to $500.0 \mu \mathrm{g} / \mathrm{ml}$ ) inhibited the increased binding of splenocytes from streptozotocin-injected mice to RIN cells as compared to splenocytes from control mice. This in vitro anti-adhesive effect was detected when either splenocytes or RIN cells were pretreated with heparin before their co-incubation, and was also obtained with $\mathrm{N}$-desulphated heparin. Heparinoids display anti-adhesive and immunomodulatory properties that are of therapeutic potential in this model of Type 1 (insulin-dependent) diabetes mellitus.

Key words: Type 1 (insulin-dependent) diabetes mellitus, streptozotocin, heparin, mice, splenocytes, Beta cell, adhesion.
The pathogenesis of Type 1 (insulin-dependent) diabetes mellitus involves anti-Beta-cell autoimmune processes [1]. "Immune" diabetes with insulitis induced in mice by low-doses of streptozotocin (STZ) [2] is useful to study these autoimmune processes and therapeutic strategies [3]. In this model, results of adoptive transfer, reconstitution experiments, and treatments with anti-lymphocyte serum or with monoclonal antibodies to L3T4 or Lyt 2, support a role for cell-mediated immunity, while humoral immunity appears to be of minor importance [4]. The ability of activated T-lymphocytes to extravasate into pancreatic islets inducing insulitis, and then adhering to Beta cells might be a target for therapeutic interventions. As demonstrated during experimental autoimmune encephalomyelitis [4], the ability of T-lymphocytes to negotiate through the vascular barrier into inflammed tissues may depend on the expression of a heparanase that degrades the heparan sulphate of the extracellular matrix. With regard to the adhesion of T-lymphocytes to Beta cells, we have reported an increased binding of circulating T-lymphocytes from Type 1 diabetic patients to membrane antigens of xenogeneic insulin-producing cells $[5,6]$. This marker, called "diabetic rosettes", can be detected before the onset of hyperglycaemia and before insulitis in low-dose STZ-treated mice [7] and in diabetes-prone NOD mice [8]. It was also detectable in some human subjects at risk for Type 1 diabetes [9]

Heparin is a glycosaminoglycan displaying, besides its anticoagulant activity, a broad spectrum of biological effects [10] including immunomodulating properties [11-14] mainly due to its ability to interact with plasma and cell membrane components [15] as well as anti-adhesive properties [16]. With regard to autoimmune diseases, low doses of heparin can suppress experimental autoimmune encephalomyelitis and adjuvant arthritis in rats [16], and may thus have a therapeutic potential in autoimmune diseases in which it would be desirable to inhibit both lympho- 
cyte traffic and the adherence of T-lymphocytes to target cells.

The aim of the present study was to investigate in vivo and in vitro the effects of heparin and $\mathrm{N}$-desulphated heparin on low-dose STZ-induced diabetes in mice. The onset and the severity of hyperglycaemia and insulitis were checked in vivo, while an inhibitory effect on the increased binding of splenocytes from STZ-treated mice to rat insulinoma (RINm5F) cells was investigated in vitro.

\section{Materials and methods}

\section{Mice, induction of diabetes, heparin and desulphated heparin treatments in vivo}

Five-week-old male CD-1 mice were purchased from Charles River France (St Aubin les Elbeuf, France), randomly distributed, and housed under conventional conditions with laboratory chow and water ad libitum. "Immune" diabetes was induced as described by Like and Rossini [2]. Streptozotocin (STZ) (Upjohn, Kalamazoo, Mich., USA) was dissolved in citrate buffer ( $\mathrm{pH} 4.5$ ), and immediately injected i.p. at doses of $40 \mathrm{mg} \cdot \mathrm{kg}^{-1}$. day ${ }^{-1}$ during five consecutive days. Control mice were treated by the vehicle of STZ. The day of the first injection of STZ was designed as day 0. "Toxic" diabetes was induced by the i. p. injection of a single high dose $(200 \mathrm{mg} / \mathrm{kg})$ of STZ . Blood samples from non-fasted mice were obtained by retro-orbital plexus bleeding without anaesthesia. Serum glucose levels were determined by the glucose oxidase method. Serial samples were obtained at the following time points: day 0 (just before the first STZ injection), days $4,9,10,12,14,16$, and 20 . The diagnosis of diabetes was made when the serum glucose level exceeded $11.0 \mathrm{mmol} / 1$.

Heparin (Roche, Neuilly, France) or N-desulphated heparin devoid of anticoagulant activity (Sigma, St Louis, Mo., USA) were diluted in phosphate buffered saline (PBS) and injected s.c. in a volume of $0.1 \mathrm{ml}$ at daily doses of $1 \mu \mathrm{g}, 5 \mu \mathrm{g}, 10 \mu \mathrm{g}$, and $200 \mu \mathrm{g}$. Nontreated mice received injections of PBS. The first injection of heparin was given at day -2 ( 2 days before the first injection of STZ) and the treatment was maintained until day 20.

\section{Histological and immunohistochemical analysis of insulitis}

Pancreases were removed into $10 \%$ formalin, embedded in paraffin, and $5 \mu \mathrm{m}$ sections were obtained. Every $10^{\text {th }}$ section was stained with haematoxylin-eosin and scored double blind as follows to assess the degree of insulitis: $(0)$ no mononuclear cell infiltration of the pancreatic islets; (1) minimal mononuclear cell infiltration restricted to one pole of $10 \%$ of at least 50 islets of the same pancreas with no infiltration seen within the islets; (2) infiltration around and within at least $30 \%$ of the islets; (3) severe infiltration within at least $60 \%$ of the islets. The scores were expressed as integer values to generate mean values \pm SEM. Five sections were examined at varying depths for each pancreas. Results are presented as the mean degree of insulitis in seven pancreases for each group.

Other pancreases were frozen in liquid nitrogen for immunohistochemical analysis of T-cell subsets in the insulitis. Cryostat sections $(5 \mu \mathrm{m})$ were acetone-fixed for $5 \mathrm{~min}$, washed with PBS, and incubated for $45 \mathrm{~min}$ with $1: 100$ diluted rat monoclonal antibodies to mice T-cell subsets: Thy 1.2 (pan-T cell), Lyt 1 (helper/inducer cells), and Lyt 2 (cytotoxic/suppressor cells). After washing, sections were incubated for $30 \mathrm{~min}$ with $1: 200$ diluted goat biotinylated antibodies to rat IgG (Vector Laboratory, Burlingame, Calif., USA). After a further $30 \mathrm{~min}$ incubation with avidin-biotin-peroxidase complex (Vector Laboratory, dilution 1:50), sections were treated for $15 \mathrm{~min}$ with $1 \mathrm{mg} / \mathrm{ml}$ diaminobenzidine (Sigma) and $0.3 \% \mathrm{H}_{2} \mathrm{O}_{2}$. The final brown colour was assessed by light microscopy. Endogenous peroxi- dase activity was blocked with methanol containing $0.3 \% \mathrm{H}_{2} \mathrm{O}_{2}$. The number of lym phocytes stained with each antibody was calculated as the percent of total lymphocytes within one given islet. The mean percentage within 15 islets was then calculated. Finally, the mean percentage \pm SEM of stained lymphocytes from five different pancreases was calculated in each group for the statistical evaluation of differences.

\section{Insulin-producing target-cell line}

The rat insulinoma RINm5F [17] cell line was maintained as a monolayer in culture flasks (Falcon, Oxnard, Calif., USA). When confluent, cells were detached and dissociated with $0.05 \%$ trypsin$0.02 \%$ EDTA at $37^{\circ} \mathrm{C}$, resuspended in RPMI containing $10 \%$ fetal calf serum (FCS; Flow, Irvine, UK), and incubated for $2 \mathrm{~h}$ at $37^{\circ} \mathrm{C}$ before experiments. RIN cells were used at culture passages less than 75 when more than $30 \%$ of the cells were still stained with A2B5 monoclonal antibody (Sera-Lab, Sussex, UK) in an indirect immunofluorescence assay (data not shown).

\section{Splenocyte isolation}

Spleens were removed in Hanks' balanced salt solution (HBSS) (Seromed, Berlin, FRG) with $2 \%$ FCS, and splenocytes were flushed from the parenchyma. Erythrocytes were lysed by ammonium chloride $\left(0.17 \mathrm{~mol} / 1 ; 10 \mathrm{~min} ; 4^{\circ} \mathrm{C}\right)$. The cell suspension was washed twice and resuspended in RPMI 1640 (Gibco, Grand Island, NY, USA) with $10 \% \mathrm{FCS}, 100 \mathrm{U} / \mathrm{ml}$ penicillin and $100 \mu \mathrm{g} / \mathrm{ml}$ streptomycin. Splenocytes were then depleted from macrophages by incubation on plastic dishes (Nunc, Rostkilde, Denmark) for $2 \mathrm{~h}$ at $37^{\circ} \mathrm{C}$. The loss of plastic-adherent cells was similar in control and STZtreated mice.

\section{RIN/splenocyte binding assay and inhibition by heparinoids}

The numeration of splenocytes adbering to RIN cells in vitro was performed as previously described [5-9]. Splenocytes from either STZ-treated or control mice $\left(1.5 \times 10^{6}\right)$ and irradiated (3000 rads) RIN cells $\left(2 \times 10^{5}\right)$ were co-incubated in $1 \mathrm{ml}$ of RPMI $+10 \%$ FCS into $5 \mathrm{ml}$ polypropylene culture tubes (Sarstedt, Numbrecht, FRG) for $18 \mathrm{~h}\left(37^{\circ} \mathrm{C} ; 5 \% \mathrm{CO}_{2}\right)$. After a careful homogenization, aliquots of the cell mixture were laid on Malassez counting chambers. Splenocytes bound and not bound to RIN cells, as well as RIN cells binding (and those free of) splenocytes were simultaneously counted under light microscopy. All the results are expressed as the total number of RIN-bound lymphocytes among the total number of splenocytes $\left(1.5 \times 10^{6}\right)$ initially seeded in each tube. Assays were performed blindly, and each mouse was tested in triplicate (intra-assay variability less than $10 \%$ ).

Inhibition experiments of this RIN/splenocyte binding by heparinoids were performed in two ways: First, heparin (final concentration: $0.1,1.0,10.0,100.0,200.0$, or $500.0 \mu \mathrm{g} / \mathrm{ml}$ ) was added to the $\mathrm{RIN} /$ splenocyte mixture during the entire co-incubation period $(18 \mathrm{~h})$. Similar inhibition experiments were performed with $\mathrm{N}$-desulphated heparin. Secondly, either the RIN cells or the splenocytes (or both) were pre-incubated for $2 \mathrm{~h}\left(37^{\circ} \mathrm{C} ; 5 \% \mathrm{CO}_{2}\right)$ with heparin $(500.0 \mu \mathrm{g} / \mathrm{ml})$ and then washed. After these washes, treated or untreated RIN cells were co-incubated with treated or untreated splenocytes for $18 \mathrm{~h}$ as described above.

\section{Statistical analysis}

Data are presented as mean values \pm SEM, and statistical differences between groups were evaluated using the two-tailed Student's $t$ test for independent samples or the non parametric $U$ test when 
$n<5$. $p<0.05$ was considered as significant. The $\chi^{2}$ test was performed to evaluate the significance of differences between percentages.

\section{Results}

Effects of heparin and of $N$-desulphated heparin on low-dose STZ-induced hyperglycaemia

Mice receiving five low doses $\left(40 \mathrm{mg} \cdot \mathrm{kg}^{-1} \cdot \mathrm{day}^{-1}\right)$ of STZ $(n=30)$ developed hyperglycaemia by the 9 th day after the first STZ injection (Fig. 1). Thereafter, the serum glucose level and the incidence of diabetes increased progressively until it reached $80 \%$. Administration of $5 \mu \mathrm{g}$ or $10 \mu \mathrm{g} / \mathrm{day}$ of heparin $(n=30$ each) led to a two-day delay in the onset of hyperglycaemia and to a statistical decrease $(p<0.01)$ of the severity of hyperglycaemia (Fig. 1). Moreover, heparin $(5 \mu \mathrm{g}$ or $10 \mu \mathrm{g} / \mathrm{day})$ reduced $(p<0.01)$ the incidence of diabetes $(80 \%$ vs $50 \%$ by day 20 after the first injection of STZ. Administration of a lower dose $(1 \mu \mathrm{g} /$ day $)$ or of a higher dose ( $200 \mu \mathrm{g} /$ day) of heparin had no effects of STZ-induced diabetes (Fig. 1). Figure 1 also shows that when, instead of heparin, CD 1 mice were treated daily with $5 \mu \mathrm{g}$ of $\mathrm{N}$-desulphated heparin $(n=30)$ devoided of anti-coagulant activity, a similar attenuation of low-dose STZ-induced diabetes was observed. Heparin $(10 \mu \mathrm{g})$ did not modify the onset or the severity of hyperglycaemia in CD 1 mice injected with a single high "toxic" dose of STZ: by 3 days following the single injection of STZ, the glycaemia was $19.5 \pm 2.7 \mathrm{mmol} / \mathrm{l}$ in the heparininjected mice, and $20.9 \pm 2.3 \mathrm{mmol} / 1$ in the non-heparintreated mice $(n=15$ each).

\section{Effects of heparin and of $N$-desulphated heparin on low-dose STZ-induced insulitis}

Mice injected with five doses of STZ displayed insulitis. The degree of this insulitis increased with time between the 8th and the 14th day following the first STZ injection (Table 1). Administration of heparin $(5 \mu \mathrm{g}$ or $10 \mu \mathrm{g})$ led to a delay in the onset of insulitis and to a decrease in the degree of this process (Table 1 ). Table 1 also shows that $5 \mu \mathrm{g}$

Table 1. Evolutive degree of insulitis in CD1-mice injected with five daily low doses $(40 \mathrm{mg} / \mathrm{kg}$ ) of streptozotocin (STZ). Mice were treated, or not, with increasing doses of heparin or of $\mathrm{N}$-desulphated heparin. Seven animals were included at each point. The degrees were scored as indicated in Materials and methods. The day of the first injection of STZ was designed as day 0

\begin{tabular}{llllll}
\hline $\begin{array}{l}\text { Daily heparin } \\
\text { dose }(\mu \mathrm{g})\end{array}$ & \multicolumn{4}{l}{ Degree of insulitis } \\
\cline { 2 - 6 } & \multicolumn{4}{l}{ Days (related to the first STZ-injection) } \\
\cline { 2 - 6 } & 6 & 8 & 10 & 12 & 14 \\
\hline None & $0.1 \pm 0.1$ & $0.9 \pm 0.3$ & $1.6 \pm 0.2$ & $2.6 \pm 0.2$ & $2.8 \pm 0.1$ \\
1 & $0.1 \pm 0.1$ & $0.8 \pm 0.3$ & $1.7 \pm 0.3$ & $2.6 \pm 0.3$ & $2.7 \pm 0.2$ \\
5 & $0.1 \pm 0.1$ & $0.2 \pm 0.2$ & $0.7 \pm 0.1$ & $1.0 \pm 0.3$ & $1.4 \pm 0.2$ \\
10 & $0.1 \pm 0.1$ & $0.2 \pm 0.2$ & $0.6 \pm 0.2$ & $1.1 \pm 0.2$ & $1.4 \pm 0.3$ \\
200 & $0.1 \pm 0.1$ & $0.8 \pm 0.3$ & $1.5 \pm 0.2$ & $2.5 \pm 0.3$ & $2.7 \pm 0.3$ \\
N-desulphated & & & & & \\
heparin $(5 \mu \mathrm{g})$ & $0.1 \pm 0.1$ & $0.2 \pm 0.1$ & $0.8 \pm 0.2$ & $1.2 \pm 0.2$ & $1.6 \pm 0.2$ \\
\hline
\end{tabular}

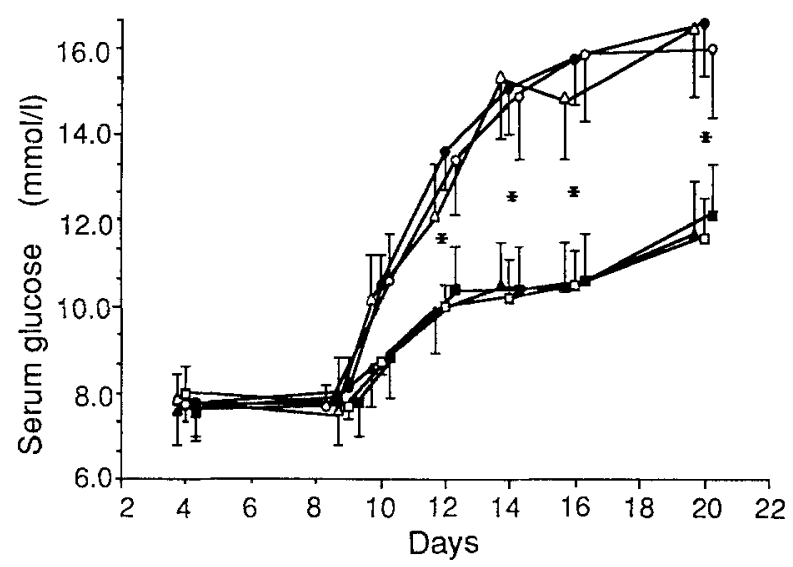

Fig. 1. Serum glucose levels in CD-1 mice ( $n=30$ in each group) receiving low doses of streptozotocin (STZ) only (-), or treated concomitantly with heparin at four different daily doses: $1 \mu \mathrm{g}(\Delta), 5 \mu \mathrm{g}$ $(\square), 10 \mu g(\Delta), 200 \mu g(O)$. CD-1 mice treated concomitantly with $5 \mu \mathrm{g}$ of N-desulphated heparin ( $)$ are also presented. Asterisks denote statistical differences from STZ-treated but non-heparintreated mice $(* p<0.01)$

of $\mathrm{N}$-desulphated heparin similarly attenuated the insulitis process. Administration of either $1 \mu \mathrm{g}$ or $200 \mu \mathrm{g}$ of heparin had no inhibitory effects on insulitis.

The immunohistochemical analysis of the insulitis observed by day 12 following the first STZ injection revealed a predominant infiltration by Thy $1.2^{+}$cells in low-dose STZ-treated mice receiving, or not receiving $10 \mu \mathrm{g} /$ day of heparin ( $80 \pm 13 \%$ vs $79 \pm 15 \% ; n=5$ in each group). In the insulitis of heparin-injected mice, Lyt $1^{+}$cells were more numerous than Lyt $2^{+}$cells $(56 \pm 16 \%$ vs $32 \pm 11 \%$, $p<0.01$ ). This predominance of the Lyt 1 subset was similarly recorded in STZ-treated mice that did not receive heparin $(54 \pm 17 \%$ vs $34 \pm 14 \% p<0.01)$.

$R I N$-adherence of splenocytes from low-dose STZ-treated mice and inhibition by heparinoids

The number of RIN-adherent splenocytes was statistically $(p<0.001)$ higher in STZ $\left(40 \mathrm{mg} \cdot \mathrm{kg}^{-1} \cdot \mathrm{day}^{-1}\right)$-treated mice $(n=30)$ than in control mice $(n=30): 28000 \pm 1000$ vs $14900 \pm 920$ (Fig. 2). This increased number of RINbinding splenocytes from STZ-treated mice was abolished when heparin was added to the medium from the initiation until the end $(18 \mathrm{~h})$ of the RIN/splenocytes coincubation period (Fig, 2). This inhibition was dosedependent: undetectable with $0.1 \mu \mathrm{g} / \mathrm{ml}$ and maximal $(p<0.001)$ at $200.0 \mu \mathrm{g} / \mathrm{ml}$ when the number of RIN-binding splenocytes from STZ-treated mice returned to the "background" control level. A similar dose-dependent inhibition of the increased number of RIN-binding splenocytes from STZ-treated mice was also obtained with $\mathrm{N}$-desulphated heparin $(n=5)$ : undetectable until $10.0 \mu \mathrm{g} / \mathrm{ml}(24000 \pm 1100)$ and complete at $200.0 \mu \mathrm{g} / \mathrm{ml}$ $(14800 \pm 1000)$. This increased number of RIN-binding splenocytes from STZ-treated mice was also inhibited when either RIN cells or splenocytes were pre-incubated for $2 \mathrm{~h}$ with heparin $(500.0 \mu \mathrm{g} / \mathrm{ml})$ before being washed and co-incubated (Fig. 3). 


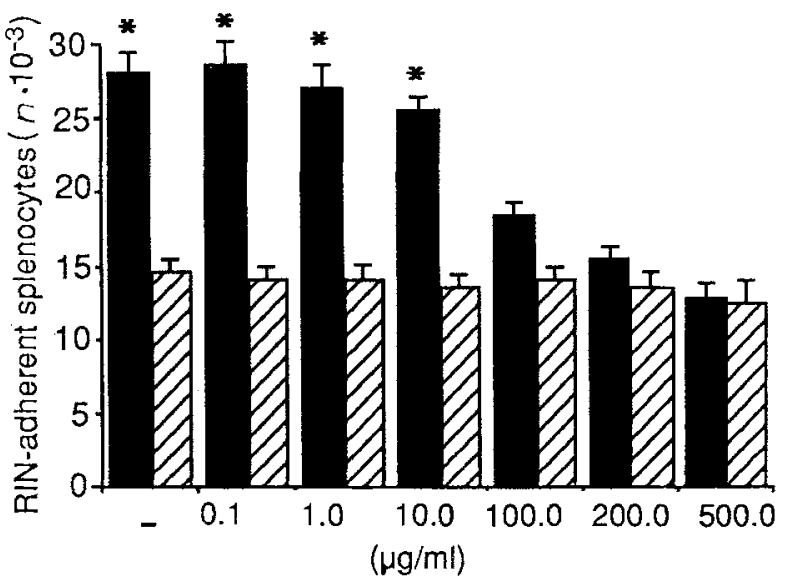

Fig. 2. Numbers of RIN-adherent splenocytes in low-dose STZ treated or control CD-1 mice. The RIN/splenocyte mixture was coincubated during the entire period $(18 \mathrm{~h})$ either in the absence or in the presence of increasing concentrations $(\mu \mathrm{g} / \mathrm{ml})$ of heparin (STZtreated mice: $\mathbf{n}$; control mice: Asterisks denote statistical differences between STZ-treated and control mice $\left({ }^{*} p<0.001\right)$. Each point represents $n=5$

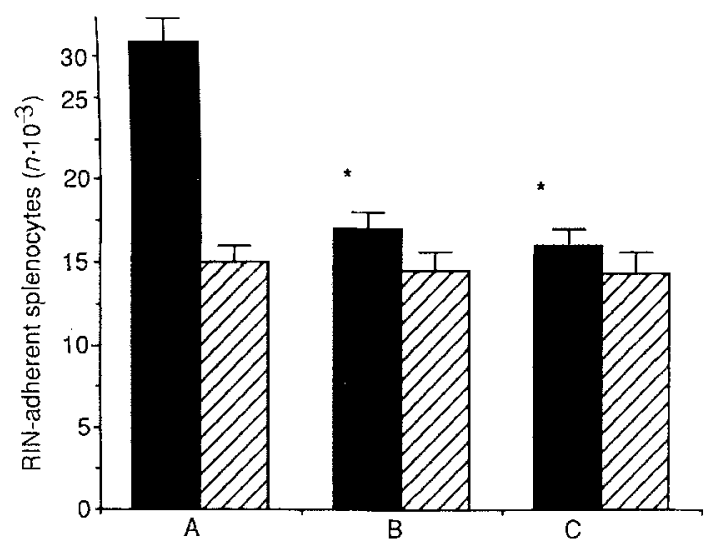

Fig.3. Numbers of RIN-adherent splenocytes in STZ-treated ( $\mathbf{m}$ ) or control ( $)$ CD 1 mice. Either RIN cells (B), or splenocytes (C), were pre-incubated for $2 \mathrm{~h}$ in the presence of heparin $(500.0 \mu \mathrm{g} / \mathrm{ml})$, washed and then co-incubated for $18 \mathrm{~h}$. Asterisks denote statistical differences from the "spontaneous" binding (A) in the absence of pre-incubation with heparin $(* p<0.01)$. Each column represents $n=5$

\section{Discussion}

The present results show that low doses of heparin were able to delay the onset and to reduce the severity and the incidence of low-dose STZ-induced "immune" diabetes and insulitis. Furthermore, the increased RIN-binding in vitro of splenocytes from STZ-treated mice, as compared to control animals, was dose-dependently inhibited by heparin.

Since cell-mediated immunity plays a role in this animal model, it is regarded as useful for studies concerning immunological manipulations of Type 1 diabetes [3]. As in all autoimmune diseases, the extravasation of lymphocytes through the target-vascular barrier, and the adherence of lymphocytes to the target cells may represent critical steps of the immune aggression of Beta cells leading to Type 1 diabetes. The glycosaminoglycan heparin is a crude mix- ture of ill-defined molecules $\left(M_{r} 12000\right.$ to 20000$)$. In addition to its anticoagulant activity, heparin has numerous biological effects, including immunomodulatory effects on lymphocytes, mainly due to interactions with plasma and cellmembrane components $[15,23,24]$. Effects on delayedtype hypersensitivity, allogeneic mixed lymphocyte reaction, mitogen- or antigen-induced blastogenesis, and cytotoxicity of natural killer cells have also been described [25-27]. Heparin also demonstrates anti-tumour activity [28]. It inhibits the infection of human T-lymphocytes by the HIV virus by interacting with the CD4 molecule [29] and inhibiting HIV adsorption. It induces lymphocytosis and influences the traffic of lymphocytes [30]. Concerning autoimmune diseases, low doses of heparin inhibit expression of heparanase by T-lymphocytes [31], experimental autoimmune encephalomyelitis, adjuvant arthritis in rats, and allograft rejection in mice $[16,32]$.

In our study, heparin has attenuated the low-dose STZinduced diabetes in mice. We cannot comment about the mechanisms for this attenuation. The finding that heparin had no beneficial effect on "toxic" diabetes induced by a single high dose of STZ was probably not due to an interference of heparin with the STZ action on Beta cells, but rather was the result of a complex of effects since heparin is a mixture of molecules that interact with many cell types and binding sites. In any case, these effects impede the penetration of the islets by lymphocytes and thus reduce the severity of insulitis. This effect was directed against both L3T4 and Lyt 2 cells since the proportion of these two subsets within the insulitis was similar both in the presence or in the absence of heparin. The fact that heparin was only partially protective may be accounted for by two complementary explanations. On the one hand, this may be due to the fact that part of the hyperglycaemia induced by low doses of STZ is not due to immune mechanisms but to the cumulative toxicity of the drug on Beta cells [33]. Monoclonal antibodies to L3T4 or Lyt 2 or antilymphocyte serum only attenuate the hyperglycaemia in this model [3] and, similarly, the cumulative toxicity of STZ to Beta cells was probably not inhibited by heparin, as suggested by the absence of effect of heparin on "toxic" diabetes induced by a single high dose of STZ. On the other hand, heparin was only effective in limiting (and not completely inhibiting) the extravasation through the isletvascular barrier leading to insulitis. Such a partial effect of heparin was also revealed during skin allograft rejection and adoptively transferred experimental autoimmune encephalomyelitis $[16,32]$. This may reflect the refractoriness of the immune system to complete inhibition by this therapeutic strategy. In any case, the in vivo effects of heparin described here and previously by others [16] were unrelated to the effects on coagulation, although coagulation plays a role in cellular immune reactions: $N$-desulphated heparin depleted for anticoagulant activity was also effective, and the doses used are lower than those required for anticoagulation. In a previous study [16], heparin displayed a specific inhibitory effect on T-lymphocyte heparanase expression that was less effective at high doses than it was at low doses both in vivo and in vitro. This decreased expression of heparanase by T-lymphocytes may have accounted for the surprising dose-re- 
sponse also observed in our study. Since heparin is a mixture of ill-defined molecules, only some of which are inhibitors of heparanase, other components may have displayed biological activities counteracting, at the higher doses, the inhibitors of heparanase.

Moreover, our results reveal an inhibitory effect of heparin and N-desulphated heparin on the increased adherence of splenocytes from STZ-treated mice to rat insulinoma cells. We can only assume that this in vitro anti-adhesive property may have been involved in the attenuation of STZ-induced diabetes. Rat insulinoma cells are not identical to normal Beta cells, and display a xenogeneic system in relation to mouse splenocytes and Beta cells. Furthermore, the loss of effectiveness of heparin in vivo at the highest doses when high doses were effective in vitro, suggests that the inhibition of adherence observed in vitro may not be the major mechanism accounting for the attenuation of diabetes. This in vitro effect resulted from a binding of heparin to both splenocytes and RIN cells. The biochemical nature and function of the binding sites are not known. Concerning lymphocytes, binding sites for heparinoids have been reported on CD4 [11] and on other glycoproteins including members of the immunoglobulin gene superfamily [15]. We can only speculate from our results that these binding sites were located both on L3T4 and Lyt 2 splenocytes which are involved in the generation of "diabetic rosettes" in STZtreated mice [7] as well as in NOD mice [8]. Furthermore, we provide the first suggestion for heparin-binding sites on RINm5F cells. This might be analysed further with regard to the potential implication of these sites to the adherence of T-lymphocytes from diabetic patients or animals to their target cells, even if Beta cells may show differing binding sites compared with the tumour cells used in our study. The molecules involved in the increased RIN cell adherence of lymphocytes from STZ-treated mice, as well as from NOD mice and from Type 1 diabetic patients, are expressed on plasma membranes [5-9], and two complementary mechanisms may account for the occurrence of "diabetic rosettes". First, they may be due to the recognition of antigens by xenogeneic T-lymphocytes in the absence of "classic" MHC-restriction [34-36]. Second, they may involve adhesion molecules for lymphocytes, such as ICAM-1 and LFA3 preliminarily documented in human islets [37,38]. Nevertheless, relatively low doses of heparin may thus have a therapeutic potential in "autoimmune" diabetes by attenuating the insulitis and the binding of T-lymphocytes to Beta cells.

Acknowledgments. We thank Ms. N. Denoual for secretarial assistance. This work was supported by grants from INSERM, Fondation pour la Recherche Médicale, Caisse Régionale d'Assurance Maladie de Loire-Atlantique, and Direction Régionale des Affaires Sanitaires et Sociales des Pays de Loire.

\section{References}

1. Eisenbarth GS (1986) Type I diabetes mellitus. A chronic autoimmune disease. N Engl J Med 314: 1360-1367

2. Like AA, Rossini AA (1976) Streptozotocin-induced pancreatic insulitis: new model of diabetes mellitus. Science 193: 415-417
3. Kolb H (1987) Mouse models of insulin-dependent diabetes. Low-dose streptozotocin-induced diabetes and nonobese diabetic (NOD) mice. Diabetes Metab Rev 3: 751-778

4. Naparstek Y, Cohen IR, Fuks Z, Vlodavsky I (1984) Activated $T$ lymphocytes produce a matrix-degrading heparan sulfate endoglycosidase. Nature 310: 241-243

5. Lang F, Maugendre D, Houssaint E, Charbonnel B, Saï P (1987) Cytoadherence of lymphocytes from type 1 diabetics to insulin secreting cells: a marker of anti- $\beta$ cell cellular immunity. Diabetes 36: 1356-1364

6. Segain JP, Valentin A, Bardet S et al. (1989) In vitro relationship of CD 4 cells from type 1 diabetic patients and xenogeneic $\beta$-cell membranes. Diabetes 38: 634-640

7. Fève B, Segain JP, Charbonnel B, Saï P (1990) $\beta$-cell adherent splenocytes precede the onset of diabetes in low-dose streptozotocin-treated mice. Diabetologia 39: 9-14

8. Fève B, Ritz P, Charbonnel B, Saï P (1990) Early detection in NOD mice of T-splenocytes binding to xenogeneic $\beta$-cell membrane sialilated proteins and of insulin autoantibodies. Diabetes 39: 101A (Abstract)

9. Bardet S, Rohmer V, Maugendre D et al. (1990) $\beta$-cell cytoadherent lymphocytes in some subjects at risk for Type 1 diabetes. Progression to diabetes within 2 years. J Clin Endocrinol Metab 71: $1310-1317$

10. Jaques LB (1979) An old drug with a new paradigm. Science 206: $528-533$

11. Lederman S, Gulick R, Chess W (1989) Dextran sulfate and heparin interact with CD4 molecules to inhibit the binding of coat protein (gp120) of HIV. J Immunol 143: 1149-1154

12. Currie GA (1967) Effect of heparin on mixed lymphocyte cultures. Nature 215: 164-166

13. Sy MS, Schneeberger E, McCluskey R, Greene MI, Rosenberg RD, Benacerraf B (1983) Inhibition of delayed-type hypersensitivity by heparin depleted of anticoagulant activity. Cell Immunol $82: 23-27$

14. Eskinasi DP, Perna JJ, Ershow AG, Sharrow SO (1988) Effects of heparin on in vitro immune parameters. J Biol Response Mod 7: 173-176

15. Parish CR, Snoweden JM (1985) Lymphocytes express a diverse array of specific receptors for sulfated polysaccharides. Cell Immunol 91: 201-205

16. Lider O, Baharav E, Mekori YA, Miller T, Naparstek Y, Vlodavsky I, Cohen IR (1989) Suppression of experimental autoimmune diseases and prolongation of allograft survival by treatment of animals with low doses of heparins. J Clin Invest 83 : $752-756$

17. Gazdar AF, Chick WL, Oie HK, Sims HL, King DL, Weir G, Lauris V (1980) Continuous, clonal, insulin- and somatostatinsecreting cell lines established from a transplantable rat islet-cell tumour. Proc Natl Acad Sci USA 77: 3519-3523

18. McEvoy RC, Andersson J, Sandler S, Hellerström C (1984) Multiple low-dose streptozotocin-induced diabetes in the mouse. Evidence for stimulation of a cytotoxic cellular immune response against an insulin-producing beta cell line. J Clin Invest 74: 715-722

19. McEvoy RC, Thomas NM, Hellerström C, Ginsberg-Fellner F, Moran TM (1987) Multiple low-dose streptozotocin-induced diabetes in the mouse: further evidence for involvement of an anti-Beta cell cytotoxic cellular auto-immune response. Diabetologia 30: 232-238

20. Cockfield SW, Ramassar V, Hurmson J, Halloran PF (1989) Multiple low dose streptozotocin induces systemic MHC expression in mice by triggering T cells to release IFN $-\gamma$. J Immunol 142: $1120-1128$

21. Paik SG, Fleischer N, Shin SI (1980) Insulin-dependent diabetes mellitus induced by subdiabetogenic doses of streptozotocin obligatory role of cell mediated autoimmune processes. Proc Natl Acad Sci USA 77: 6129-6133

22. Kiesel U, Kolb H (1983) Suppressive effect of antibodies to immune response gene products on the development of low-dose streptozotocin. Diabetes 32: 869-871 
23. Schreiber AB, Kenney J, Kowalski WJ, Friesel R, Mehlman T, Maciag T (1985) Interaction of endothelial cell growth factor with heparin: characterization by receptor and antibody recognition. Proc Natl Acad Sci USA 82: 6138-6152

24. Roberts R, Callagher I, Spooncer E, Allen TD, Bloomfield F, Dexter TM (1988) Heparan sulphate bound growth factors: a mechanism for stromal mediated haemopoiesis. Nature 332: 376-378

25. Sy MS, Schneeberger E, McCluskey R, Greene MI, Rosenberg RD, Benacerraf B (1983) Inhibition of delayed-type hypersensitivity by heparin depleted of anticoagulant activity. Cell Immunol 82:23-32

26. Dziarski R (1989) Enhancement of mixed leukocyte reaction and cytotoxic antitumor responses by heparin. J Immunol 143: 356-365

27. Gorelik E, Bere WW, Herberman RB (1984) Role of NK cells in the antimetastatic effect of anticoagulant drugs. Int J Cancer 33: $87-91$

28. Coombe DR, Parish CR, Ramshaw IA, Snowden JM (1987) Analysis of the inhibition of tumor metastasis by sulphated polysaccharides? Int J Cancer 39: 82-86

29. Mitsuya H, Looney DJ, Kuno S, Ueno R, Wong-Staal F, Broder S (1988) Dextran sulfate suppression of viruses in the HIV family: inhibition of virion binding to $\mathrm{CD} 4^{*}$ cells. Science 240: 646-648

30. Sasaki S (1967) Production of lymphocytosis by polysaccharide polysulphates (heparinoids). Nature 214: 1041-1042

31. Bar-Ner M, Eldor A, Wasserman L, Matzner Y, Cohen IR, Fuks Z, Vlodavsky I (1987) Inhibition of heparanase mediated degradation of extracellular matrix heparan sulfate by non anticoagulant heparin species. Blood 70: 551-557

32. Chelmika-Szone E, Arnason BGW (1972) Partial suppression of experimental allergic encephalomyelitis with heparin. Arch Neurol 27: 153-158
33. Bonnevie-Nielsen V, Steffes MW, Lernmark $\AA$ (1981) A major loss in islet mass and $\beta$-cell function precedes hyperglycemia in mice given multiple low doses of streptozotocin. Diabetes 30 : 424-429

34. Altmann DM, Lider O, Douek DC, Cohen IR (1987) Activation of specific $T$ cell lines by the antigens avidin and myelin basic protein in the absence of antigen-presenting cells. Eur J Immunol 17: $1635-1640$

35. Boitard C, Chatenoud LM, Debray-Sachs M (1982) In vitro inhibition of pancreatic $\beta$-cell function by lymphocytes from diabetics with associated autoimmune diseases: a $T$ cell phenomenon. J Immunol 129: 2529-2531

36. Jewtoukoff V, Bach MA (1988) Non MHC-restricted tissue-specific $T$ cells recognizing autologous oligodendrocytes in the nor$\mathrm{mal} \mathrm{SLJ/J}$ mouse. J Autoimmun 1: 433-444

37. Pujol-Borrell R, Vives M, Badenas J, Foz M, Buscema M, Soldevila G, Bottazzo GF (1989) Modulation of intercellular adhesion molecule-1 (ICAM-1) expression in human islet cells. Diabetes 38 [Suppl 2]: $190 \mathrm{~A}$ (Abstract)

38. Campbell IL, Cutri A, Wilkinson D, Boyd AW, Harrison LC (1989) Intercellular adhesion molecule 1 is induced on isolated endocrine cells by cytokines but not by reovirus infection. Proc Natl Acad Sci USA 86: 4282-4286

Received: 6 July 1990

and in revised form: 22 November 1990

Dr.P.Saï

Laboratoire d'Immunologie du Diabète

Faculté de Médecine

1 rue Gaston Veil

F-44035 Nantes

France 